DOI: $10.12775 /$ szhf.2013.005

\title{
Polskie badania nad filozofią brytyjskiego empiryzmu (lata 1760-1918), cz. II
}

W drugiej części naszego sprawozdania inwentaryzacyjnego przedstawimy polskie osiągnięcia dawne w zakresie badań nad filozofią Francisa Bacona, Isaaka Newtona, tudzież innych pomniejszych filozofów ${ }^{1}$.

\section{Francis Bacon}

W Warszawie w latach 1773-1775 ukazała się Kajetana Józefa Skrzetuskiego Historia polityczna dla szlachetnej młodzi. W części drugiej tej pracy na stronach 385-390 znajdziemy uwagi poświęcone filozofii Bacona.

Karol Libelt w „Tygodniku Literackim Warszawskim”, t. 3, z 1840 roku, dziele wydawanym w częściach pisał o Filozofii przedmiotowej, głównie tej Schellinga i Hegla, ale też o Locke’m i Baconie.

${ }^{1} \mathrm{~W}$ naszych badaniach opieramy się na przeprowadzonych kwerendach bibliotecznych, a także na Bibliografii filozofii polskiej, opracowywanej od lat z inicjatywy Komitetu Redakcyjnego Biblioteki Klasyków Filozofii na podstawie materiałów zebranych przez Adama Bara. Są to tomy: obejmujące lata 1750-1830, Warszawa 1955, ss. 265; lata 1831-1864, opracowały A. Kadler i I. Raczyńska przy współudziale B. Skargi i A. Sawickiej, Warszawa 1960, ss. 411; lata 1865-1895, opracował zespół pod kierownictwem A. Kadler, Warszawa 1971, ss. 705; lata 1896-1918, z. 1, do druku opracowali A. Przymusiała i M. Młoczkowska z udziałem J. Jaworowskiego, Warszawa 1994, ss. 479 oraz z. 2, do druku opracowali A. Przymusiała i M. Młoczkowska z udziałem J. Jaworowskiego i P. Dlouhy, Warszawa 2002, ss. 391. 
Lekarz Erazm Majewski opublikował na łamach „Pamiętnika Towarzystwa Lekarskiego Warszawskiego" własną rozprawę odczytaną na publicznym posiedzeniu Warszawskiego Towarzystwa Lekarskiego w dniu 20 stycznia 1850 roku O wplywie metody Bacona na postępy nauki lekarskiej w ostatnich wiekach. Recenzje z tej pracy ukazały się w "Gazecie Warszawskiej” i w „Tygodniku Petersburskim”.

W pracy Postrzeżenia nad wiekiem XIV. Włochy znajdziemy uwagi jej autora Antoniego Stadnickiego O metodzie Bacona oraz o pojęciu wolnej woli u św. Tomasza, na stronach 221-223 w tzw. przypisie 3. Praca ukazała się w Krakowie w 1837 roku.

Aleksander Tyszyński wydał w „Bibliotece Warszawskiej” w 1860 roku w t. 4, s. 469-498, pracę pt. Trzy loiki, czyli jaką powinna być loika, gdzie znajdziemy między innymi uwagi o logice Bacona.

Pierwszą polską pracą o Baconie były rozważania Michała Wiszniewskiego pt. Bakona metoda tłumaczenia natury, która wyłożył i przydat wiadomość o Sędziwoju, alchemiku polskim, Kraków 1834, ss. 215.

Józef Jerzy Boguski wygłosił wykład na Akademickich Kursach Cukrowniczych w dniu 30 maja 1912 roku pt. Stanowisko nauk technicznych w ogólnym ich układzie. Był to rzut oka na układ nauk w propozycjach Bacona, Comte’a i Spencera. Podobną pracę opublikował Józef Bohdan Oczapowski w „Bibliotece Warszawskiej” z 1880 w t. 4, s. 329-347 pt. Poglą na obecny stan filozofii społecznej w systemacie umiejętności. Był to rzut oka na klasyfikacje nauk dokonane przez Fr. Bacona, d'Alemberta, Welkera, Ventury, Comte’a.

Władysław Deisenberg w Dziejach filozofii prawa i państwa przedstawionych na tle dziejów cywilizacji w t. 1 dotyczącym filozofii nowożytnej, a wydawanych w Krakowie w latach 1872-1881, poświęcił wiele uwag filozofii Bacona na s. 287-332.

Hipolit Grzybowski w „Gazecie Polskiej Warszawskiej” z 1867 roku w nr 232, s. 1-3, przedstawił kilka uwag o filozofii Bacona.

Kazimierz Kraszewski w „Bibliotece Warszawskiej” z 1877 roku w t. 1, s. 204-231 opublikował artykuł pt. Metoda Bacona między innymi na podstawie pracy Michała Wiszniewskiego pt. Bakona metoda tłumaczenia natury, która wyłożył i przydał wiadomość o Sędziwoju, alchemiku polskim, Kraków 1834, ss. 215.

Franciszek Salezy Krupiński w „Wieńcu Warszawskim”, R. 1 z 1872, w t. 1 opublikował pracę w częściach pt. Wczasy warszawskie, a w rozdz. 6 uwagi o utopijnych poglądach Morusa, Platona, Campanelli, Fr. Bacona i Krasickiego, jak również o idei równouprawnienia kobiet i mężczyzn jako utopii. 
Henryk Struve w „Wykazie Szkoły Głównej Warszawskiej” z półrocza zimowego, na przełomie lat $1864 / 1865$, na s. 5-26 opublikował pracę pt. O psychologicznej zasadzie teorii poznania (s. 9-12 poświęcone zostały omówieniu poglądów filozoficznych Bacona).

Józef Tokarzewski opublikował w „Tygodniku Nauk Lwowskim” w 1865 roku, na s. 530-535 niedokończony artykuł pt. Fr. Bacon, jego życie i filozofia.

Wojciech Urbański opublikował w „Przewodniku Nauk Literackich Lwowskich" w R. 2, z 1874 roku, w t. 1, s. 467-470 pracę pt. Stosunek Bakona Werulamskiego do dzisiejszej metody w naukach przyrodniczych.

Stanisław Zarański opublikował w Krakowie w 1882 roku pracę pt. Nowy organ dydaktyki wedtug metody Bacona, ss. 303. W tejże pracy został też zawarty przekład ks. 1-2 z Novum Organum Bacona, s. 75-167.

Ksawery Franciszek Mroczko opublikował w "Szkole Lwowskiej” w t. 28 z 1891 roku na s. 147-149, 160-161, 174-175, 184-185, pracę pt. Lord pedagog Francis Bacon (Szkic biograficzny).

Bronisław Bandrowski w „Sprawozdaniach Gimnazjum Franciszka Józefa we Lwowie" z roku szkolnego 1904 na s. 1-43 opublikował pracę O metodach badania indukcyjnego. O pogladach Fr. Bacona, J. Herschela, J. St. Milla, Ch. Sigwarta.

Józef Gąbiński we Lwowie w 1899 roku opublikował liczącą 107 stron pracę Wiedza czy wiara?. Praca poświęcona omówieniu możliwości poznawczych umysłu ludzkiego od Fr. Bacona do Kanta i kantystów.

Władysław Horodyski, Filozofia Lamberta w stosunku do rozwoju pogladów Kanta oraz do Bakona, Kraków 1936 („Sprawozdania Polskiej Akademii Umiejętności”, t. 21, 1916, nr 9, 21-33).

Stanisław Piotrkowski opublikował w Warszawie 1930 roku liczącą 300 stron pracę Szkice socjologiczne, a na stronach 82-95 omówił poglądy Bodina i Bacona.

W 1909 roku w Warszawie ukazały się w polskim przekładzie Stanisława Pyrowicza Fr. Bacona Szkice polityczno-etyczne, ss. 131 (pierwsze 23 szkice wyd. łacińskiego Sermones Fidelem seu interiora rerum). Ukazały się też recenzje W. Dunina w „Bibliotece Warszawskiej” i I. Myślickiego w „Książce Warszawskiej”.

Adolf Strzelecki w „Przeglądzie Polskim Krakowskim” w t. 127 z 1898 w z. 9 w częściach opublikował pracę pt. Szekspir i Bakon. Wiele hałasu o nic.

Marian Nitecki w Warszawie w 1916 roku opublikował książkę pt. Bacon Wrulamski wobec filozofii wiecznej, ss. 200. Praca miała liczne recenzje m.in. pióra A. Niemojewskiego, I. Matuszewskiego, Wł. Rabskiego i D. Zglińskiego. 


\section{Isaac Newton}

W „Pamiętniku Magnetackim Wileńskim” w 1817 roku wyszedł w tłumaczeniu anonimowym Wyjątek $z$ dzieła Pierre Hourcastremé Essais d'un appenti philosophe pt. Zapytania i wattpliwości, czyli rozmowa ucznia filozofa $z$ Newtonem i Kartezjuszem, razem dwie strony.

W polskim tłumaczeniu Wincentego Turskiego Kondyllaka O nauce historii, jako też stosowany dodatek wyjęty $z$ dzieł sławniejszych pisarzów $w$ wieku zeszłym, w wydanym w Warszawie 1812 roku, znajdziemy uwagi o Voltaire’a rozważaniach O niewinności, czyli kilka słów do Elementów filozofii Newtona, na stronach 216-220. Dzieło to pierwotnie przypisane jest Gabrielowi Mably de Bonnotowi. Później dopiero weszło w skład dzieł jego brata Condillaca Cours détudes pour le psince de Parme i Cours détudes pour les jeunes gens.

W Warszawie w latach 1773-1775 ukazała się Kajetana Józefa Skrzetuskiego Historia polityczna dla szlachetnej młodzi. W części drugiej tej pracy na stronach 427-432 znajdziemy uwagi poświęcone filozofii Newtona.

Jan Czyński w pracy Kopernik est ses travaux, wydanej w Paryżu w 1847 roku, na s. 283-287 zawarł kilka uwag o Newtonie.

Józef Żochowski w „Tygodniku Petersburskim” w cz. 22 z 1840 roku w nr 84 na s. 469-470 zawarł krótką notę o Źródle najpowszechniejszego i najpoważniejszego błędu w nauce Newtona. Ta nota była początkiem polemiki ze Stanisławm Starskim i Józefem Przecławskim na łamach „Tygodnika Petersburskiego".

Henryk Levittoux, lekarz i filozof, opublikował w Warszawie w 1869 roku pracę pt. Zarys filozofii natury, liczącą 236 stron, w której obok poglądów Cuviera, Hilaire’a, Flourensa, omawia też poglądy Newtona. Praca też wzbudziła szeroką krytykę zwaną warszawską, w której udział wzięli m.in. B. Strzemiński, J. Łapinki, H. F. Lewestam, J. Ochorowicz. Toczyła się ona na łamach „Biblioteki Warszawskiej”, „Gazety Polskiej”, „Kłosów” oraz „Przeglądu Tygodniowego".

Julian Ochorowicz opublikował w "Ateneum Warszawskim” pracę pt. Siła jako ruch. Studium z filozofii fizyki, w t. 3 z 1879 roku s. 538-564. Była to analiza newtonowskiej teorii ciążenia powszechnego.

Zygmunt Straszewski opublikował pracę we „Wszechświecie Warszawskim" w t. 6 z 1887 roku na s. 518-522, 530-533, pt. Zagadka ciążenia. Wyjaśniała ona newtonowskie prawa grawitacji. 
Juliusz Mastelski, leśniczy, napisał i opublikował w Warszawie w latach 1900-1904 w trzech częściach Filozofię przyrody w zarysach, w cz. 2 o zasadach matematycznych filozofii przyrody Newtona.

Ludwik Burnet we „Wszechświecie Warszawskim” w t. 17 z 1898 roku w nr 11, s. 161-166, opublikował pracę Rozwój teorii fizycznych, gdzie omówił podstawy teorii fizykalnych Kartezjusz i Newtona.

We „Wszechświecie Warszawskim” w t. 19 z 1900 roku w nr 26, 27 i 28 ukazała się w przekładzie Fr. Tomaszewskiego praca Ludwiga Boltzmanna O rozwoju metod fizyki teoretycznej w nowszych czasach. Był to przegląd postępów fizyki teoretycznej od czasów Newtona.

\section{Thomas Hobbes}

Władysław Deisemberg w Dziejach filozofii prawa i państwa przedstawionych na tle dziejów cywilizacji. Dzieje filozofii nowożytnej, Kraków 1872-1881, ss. 921, na s. 372-423 omawia poglądy Hobbesa.

Wojciech Dzieduszycki w „Bibliotece Warszawskiej” z 1882 roku, t. 4, s. 161-181 opublikował pracę Moraliści XVII wieku, gdzie uwzględnił poglądy etyczne Hobbesa.

Eugeniusz Lipnicki w „Przeglądzie Naukowym Literackim Lwowskim”, R. 22 z 1894 roku na s. 597-612, 705-714, opublikował pracę Teorie wiecznego pokoju, „Hobbes”, s. 602-603. W „Bibliotece Warszawskiej” z 1886 roku w t. 2, ukazała się natomiast praca Pesymizm i wszechwładza państwa, cz. 1 poświęcona została Hobbesowi, druga Schopenhauerowi, a trzecia E. Hartmanowi.

W „Kurierze Warszawskim” z 1888 roku nr 155, s. 1-2 i w nr 156, s. 1, ukazał się artykuł Cezarego Jellenty (Hirszband) pt. Tomasz Hobbes $w$ trzechsetna rocznicę urodzin.

\section{Polskie recepcje filozofii Benthama, Burke’a i Pope’a}

a) Filozofia J. Benthama i jej polska recepcja do 1918 roku

W „Dzienniku Wileńskim” z 1827 roku w tomie 3, s. 330-336, poświęconym historii literatury ukazała się Bibliografa przedrukowana $\mathrm{z}$ „Telegrafu Moskiewskiego" z numeru 2 z 1827 roku, zawierająca „Notę” o J. Benthamie.

W „Kwartalniku Naukowym” w tomie 1 z 1835 roku na stronie 183 można znaleźć recenzję z J. Benthama Déontologie ou la scence de la morale, t. 1-2, Bruxlleses 1834 . 
Kazimierz Kraszewski napisał artykuł poświęcony Benthamowi w „Encyklopedii Wychowawczej” w tomie 2 wydanym w Warszawie w 1882 roku na stronach 75-82.

Stefan Pawlicki napisał recenzję w "Przeglądzie Polskim Krakowskim” w roczniku 10 z 1875/1876 roku w tomie 3, s. 290-296 z pracy Georgia Grote La religion naturelle, son influence sur le bonheur du genre humain d'après les papiers de Jerôme Bentham, Paris 1875.

Zenon Przesmyki w „Varš. Univ. Izvěst.” z 1886 roku opublikował pracę pt. „Značenie popytom kodifikacii meždunarodnego prava dlja teorii i praktyki. Kritičeskoe obozrĕnie sovremennoj literatury po skazannomu voprosu. W pracy tej podane zostały wytyczne o projektach Kanta i Benthama (prawo idealnego państwa i wiecznego pokoju).

b) Filozofia E. Burke’a i jej polskie próby recepcji do 1918 roku

W „Nowym pamiętniku Warszawskim” w tomie 14 z 1804 roku na stronach 84-111 ukazał się obszerny wypis O guście Edmunda Burke’a z Badań filozoficznych nad porzadkiem naszych wyobrażeń o wysokości i piękności (z org. Philosophical Inquiry into the Orgin of our Ideas on the Sublime and Beautiful).

c) Filozofia Pope’a i jej próby recepcji do 1918 roku

Przekład ks. Andrzeja Cyankiewicza wydany w Krakowie 1788 roku A. Pope’a Początki moralności, czyli wiersz filozoficzny o człowieku, ss. 123.

Przekład prozą dokonany przez P. Targońskiego w Lublinie 1789 roku, ss. 115, jako Dociekania o człowieku, czyli początki obyczajności.

Szerzej o filozofii A. Popea traktuje publikacja Michała Dadleza Pope w Polsce w XVIII wieku, Skład Główny w Księgarniach Gebethnera i Wolffa, Kraków 1923, ss. 81.

\section{d) Inne prace}

William Pinnock, Początki logiki, przekład i komentarz Jan Iwaszkiewicz, Wilno 1830, ss. 126.

Piere Bayle, $Z$ Anglii, [wiadomości kronikarskie], w: „Wiadomości Warszawskie" 1766, nr 51, (porównanie poglądów Rousseau i Bayle’a). 
Hugo Blair (szkocki filozof oświecenia, moralista), O smaku, w: „Pamiętnik Warszawski Umiejętności Czystych Stosowanych”, 1829, t. 3, s. 5-23.

Hugo Blair, O krytyce, geniuszu, rozkoszach, smaku i wielkości w przedmiotach, w: „Pamiętnik Warszawski Umiejętności Czystych Stosowanych”, 1829, t. 3, s. 139-157.

Peter Henry Brougham, Rozprawa o celu, korzyściach i przyjemnościach $z$ umiejętności wynikających, służąca za wstęp do Encyklopedii Popularnej, $\mathrm{w}$ : „Encyklopedia popularna, obejmująca umiejętności, sztuki i rzemiosła... ogłoszona w Londynie", tłum. A. Krauze, t. 1, Warszawa 1830, s. 3-147.

Peter Henry Brougham, A discourse of natura theology showing the nature of the evidence and the advantages of the study, London 1835, [frag. w tłum. A. Horodzieńskiego, w: A. Horodzieński, Ułamek filozoficzny. Słówko o właściwym rozumieniu nazwy "filozofia” i o nieśmiertelności oraz osobności względnej do swej natury duszy od ciała $i$ wszelkiej materii, w: „Rubon”, t. 6, 1845 , s. 55-83.

Steward Dugald, Dugald Steward i szkoła szkocka. Z Timesa, tłum. F. Jegierski, w: „Biblioteka Warszawska”, 1860, t. 2, s. 562-571.

\section{Abstract \\ Polish Studies in the Philosophy of British Empiricism}

(1760-1918) part II

Keywords: British empiricism, Bacon, Newton, Hobbes, Burke

Polish studies on the philosophy of British empiricism had various courses. Polish studies on Leibniz, Spinoza or Kant were quite advanced, but we know but little about the research on British empiricism. The achievements of the attempts of reconstructing the early reception are rather vestigial. The second part of the article presents early Polish studies into the philosophy of Bacon, Newton, Hobbes and Burke. 